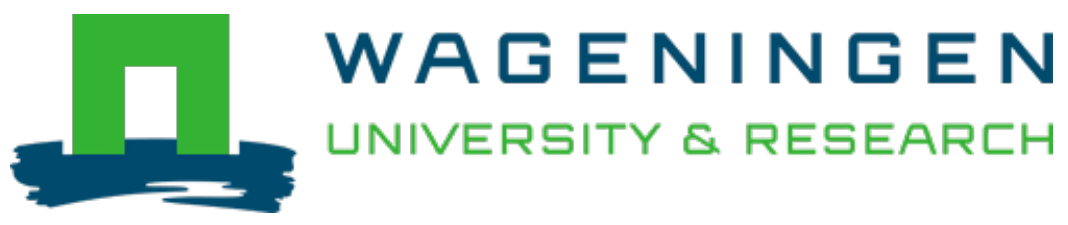

\title{
Characterization and frequency distribution of species of lactic acid bacteria involved in the processing of mawé, a fermented maize dough from Benin
}

\author{
International Journal of Food Microbiology \\ Hounhouigan, D.J.; Nout, M.J.R.; Nago, C.M.; Houben, J.H.; Rombouts, F.M. \\ https://doi.org/10.1016/0168-1605(93)90151-6
}

This publication is made publicly available in the institutional repository of Wageningen University and Research, under the terms of article $25 \mathrm{fa}$ of the Dutch Copyright Act, also known as the Amendment Taverne. This has been done with explicit consent by the author.

Article 25 fa states that the author of a short scientific work funded either wholly or partially by Dutch public funds is entitled to make that work publicly available for no consideration following a reasonable period of time after the work was first published, provided that clear reference is made to the source of the first publication of the work.

This publication is distributed under The Association of Universities in the Netherlands (VSNU) 'Article $25 \mathrm{fa}$ implementation' project. In this project research outputs of researchers employed by Dutch Universities that comply with the legal requirements of Article $25 \mathrm{fa}$ of the Dutch Copyright Act are distributed online and free of cost or other barriers in institutional repositories. Research outputs are distributed six months after their first online publication in the original published version and with proper attribution to the source of the original publication.

You are permitted to download and use the publication for personal purposes. All rights remain with the author(s) and / or copyright owner(s) of this work. Any use of the publication or parts of it other than authorised under article $25 \mathrm{fa}$ of the Dutch Copyright act is prohibited. Wageningen University \& Research and the author(s) of this publication shall not be held responsible or liable for any damages resulting from your (re)use of this publication.

For questions regarding the public availability of this publication please contact openscience.library@wur.nl 


\title{
Characterization and frequency distribution of species of lactic acid bacteria involved in the processing of mawè, a fermented maize dough from Benin
}

\author{
D.J. Hounhouigan ${ }^{\text {a }}$, M.J.R. Nout ${ }^{\text {b }}$, C.M. Nago a ${ }^{\text {a J.H. Houben }}{ }^{\mathrm{c}}$ \\ and F.M. Rombouts ${ }^{b}$ \\ a Section de Nutrition et Sciences Agro-Alimentaires, Faculté des Sciences Agronomiques, \\ Unicersité Nationale du Bénin, Cotonou, Bénin; 'Department of Food Science, Agricultural Unicersity, \\ Wageningen, The Netherlands; " Department of the Science of Foods of Animal Origin, \\ Utrecht Unicersity, Utrecht, The Netherlands
}

(Received 1 September 1992; revision received 8 January 1993; accepted 22 January 1993)

\begin{abstract}
Lactic acid bacteria involved in the natural fermentation of both home-produced and commercial mawe were investigated during a $72 \mathrm{~h}$ fermentation period. Lactobacillus spp. constitute the majority ( $94 \%)$ of the strains of the lactic acid bacteria isolated, among which $89 \%$ represent the Betabacterium group. They include $L$. fermentum (biotype cellobiosus) (41\%), L. fermentum or L. reuteri (19\%), L. brelis $(26 \%)$, L. confusus (less than $2 \%$ ), L. curvatus (less than $1 \%$ ) and L. buchneri (less than $1 \%$ ). Other isolated lactic acid bacteria were L. salicarius, Lactococcus lactis, Pediococcus pentosacens, Pediococcus acidilactici and Leuconostoc mesenteroides. Several species were detected at the early stage of fermentation, but the final stage was dominated by $L$. fermentum (biotype cellobiosus) and L. fermentum or $L$. reuteri totalling $90 \%$ of the isolated strains. The trend was the same for both home-produced and commercial mawè. No strains of $L$. plantarum, generally reported as dominating lactic acid bacteria at the final stage of fermentation of most plant foods, were isolated.
\end{abstract}

Key words: Maize; Mawè; Fermentation; Lactobacilli

\section{Introduction}

Natural fermentation of cereal grains is a common practice of food processing in West Africa. One of the most popular of these foods, especially in Benin and Togo, is mawè, a dehulled maize dough used to prepare many dishes. Production and quality attributes of mawè have been investigated (Hounhouigan et al., 1992).

Correspondence address: D.J. Hounhouigan, Section de Nutrition et Sciences Agro-Alimentaires, Faculté des Sciences Agronomiques, Université Nationale du Bénin, BP 526, Cotonou, République du Bénin. 
Two major methods of mawè production were found: (i) the home-production method, used to prepare mawè for family consumption; (ii) the commercial method, used to satisfy the demand of ready-to-cook mawè in urban areas.

Commercial mawè is produced by skilled women in privately owned milling shops. A total of 659 plate disc mills ('Premier 1A' type) were recorded in Cotonou, the capital city of Benin. They are mainly used to process cereals. Many milling shops are specialized in commercial mawè production and have a daily processing capacity of about $500-1000 \mathrm{~kg}$ of maize each. Depending on the demand, the batch sizes vary between 60 and $120 \mathrm{~kg}$ of mawè which have approximately one week of shelf life.

Lactic acid bacteria are common in fermented cereal foods (Akinrele, 1970; Christian, 1970; Nout, 1980; Fields et al., 1981; Mbugua, 1984; Gashe, 1985; Odunfa and Adeycle, 1985). No studies of the microflora responsible for the fermentation of mawè have been reported. Previous investigations showed that the dominating lactic acid bacteria in this product were Lactobacillus spp. which accounted for $10^{9} \mathrm{cfu} / \mathrm{g}$ of the product (Hounhouigan et al., 1992).

The present report describes the frequency distribution, the succession and the characteristics of different species of lactic acid bacteria isolated during a period of $72 \mathrm{~h}$ of fermentation of both home-produced and commercial mawè.

\section{Materials and Methods}

\section{Mawè preparation}

Commercial mawè was produced as follows: Sekou 85 variety of maize $(10 \mathrm{~kg})$ provided by the International Institute of Tropical Agriculture in Benin was cleaned by winnowing, washed in water and crushed. The crushed maize was sieved through $0.5 \mathrm{~mm}$ screens. The fine endosperm fraction passed through the sieve and was collected in a pan. The grits and the hulls were separated by gravity on the sieve. The hulls were discarded and the grits were collected and washed thoroughly in water. The bran floating on the surface of the washing water was discarded. The washed grits and the fine fraction which were previously collected were mixed, moistened by adding water, left to stand for $2 \mathrm{~h}$ and ground finely.

In the home-production method, the grits were not washed; after crushing, the material was sieved through $2-4 \mathrm{~mm}$ screens to remove the hulls. The resulting grits and fine fraction were moistened and left to stand for $2 \mathrm{~h}$ before milling.

The resultant flour from each process was kneaded with additional water. The final moisture content of the dough was adjusted to about $46 \%(\mathrm{w} / \mathrm{w}$,$) , using a$ Mettler LP 15 infrared unit installed on a Mettler PE 3600 electronic balance. The resulting dough from each process (about $11-12 \mathrm{~kg}$ ) was equally distributed in six plastic buckets, covered with a polyethylene sheet and allowed to ferment spontaneously for $72 \mathrm{~h}$ at room temperature $\left(28-32^{\circ} \mathrm{C}\right)$. The production was carried out in a local milling shop by a mawè producer. Duplicate experiments were carried out for each process. 


\section{Bacterial isolation and purification}

After $0,6,12,24,48$ and $72 \mathrm{~h}$ of fermentation, one bucket of mawè $(1.8-2 \mathrm{~kg})$ from each process was taken from the fermenting lot for analysis. Ten grams of mawè were then sampled under aseptic conditions. The sample was homogenized with $90 \mathrm{ml}$ sterile peptone-physiological salt solution $(5 \mathrm{~g}$ peptone, $8.5 \mathrm{~g} \mathrm{NaCl}, 1000$ $\mathrm{ml}$ distilled water, $\mathrm{pH} 7.0 \pm 0.2)$ and decimal dilutions were made. Dilutions were made into pour plates with MRS agar (Oxoid CM 361) with addition of $0.1 \%(\mathrm{w} / \mathrm{v})$ natamycin (Delvocid, Gist-Brocades, Delft, The Netherlands), with an overlay of the same medium. Incubation was carried out for $3-5$ days at $30^{\circ} \mathrm{C}$. In general, colonies representing the square root of the number present were randomly selected from plates obtained from the highest countable dilution (Harrigan and McCance, 1976). The selected colonies were isolated by streaking on MRS agar and incubated at $30^{\circ} \mathrm{C}$ for 3-5 days, using anaerobic jars and anaerobic system envelope with palladium catalyst (BBL Gas Pak Plus; Becton Dickinson). The purity of the isolated organisms was checked by streaking again on MRS agar plates, followed by microscopic examination. Subsequently they were grown on slants of MRS agar and stored at $5^{\circ} \mathrm{C}$, prior to identification.

\section{Preliminary tests and biochemical characteristics}

Preliminary tests included Gram staining on 18-h cultures, microscopic examination and catalase reaction, carried out according to the methods described by Harrigan and McCance (1976). Tests of aerobic, facultative aerobic and anaerobic growth were assessed using two inoculated tubes containing MRS broth (Oxoid CM 359) of which one was incubated aerobically at $30^{\circ} \mathrm{C}$, and the other anaerobically in an anaerobic jar as described earlier. Homo- or heterofermentative assimilation of glucose was assessed using MRS broth with Durham tubes inserted.

Growth at 15 and $45^{\circ} \mathrm{C}$ was tested in MRS broth incubated in a Memmert incubator ( 854 Schwabach W. Germany) and in a Salvis water-bath (Bioblock, France) respectively, for 10 days. If growth was possible at $45^{\circ} \mathrm{C}$, most strains showed turbidity after $24 \mathrm{~h}$.

Ability of the isolates to ferment carbohydrates was studied using the API 50 CHL system (La Balme les Grottes, 38390, Montalieu Vercieu, France). The results were recorded after $2 \vdots$ and $48 \mathrm{~h}$, as recommended by the manufacturer. Stock cultures were subcultured thrice in MRS broth before tests were performed. Production of ammonia from arginine was tested according to the method described by Harrigan and McCance (1976).

\section{Computer analysis}

Patterns of fermented carbohydrates were used for preliminary attempt of identification, using the computer-aided identification programme for lactic acid bacteria, as developed by Cox and Thomsen (1990). The bacteria were finally identified on the basis of the cell morphology, the nature of the fermentation pathway (homo- and heterofermentation) and the differential characteristics of the species, including the ability to grow at 15 and $45^{\circ} \mathrm{C}$, and the ability to produce ammonia from arginine, according to Bergey's Manual (Kandler and Weiss, 1986). 


\section{Results}

A total of 120 strains of lactic acid bacteria were isolated, examined and classified from both home-produced and commercial mawè. For this purpose, basic data including Gram-staining, morphology, gas production from glucose, growth at 15 and $45^{\circ} \mathrm{C}$, and hydrolysis of arginine were essential in addition to the pattern of assimilated carbohydrates. Frequency distributions and succession of isolated dominating species in home-produced and commercial mawè are shown in Figs. 1 and 2, respectively. Lactobacillus spp. constitute the majority (94\%) of the lactic acid bacteria isolated. This is in accordance with our previous results (Hounhouigan et al., 1992). Most of the Lactobacilli ( $89 \%$ of the isolated strains) were of the obligately heterofermentative Betabacterium group. They include L. fermentum (biotype cellobiosus), L. fermentum or $L$. reuteri and $L$. brevis which represent $85 \%$ of the strains isolated from home-produced mawè and $86 \%$ from commercial mawè. Other strains isolated were identified as L. curvatus, L. confusus, $L$. buchneri, Lactococcus lactis, Pediococcus pentosaceus, Pediococcus acidilactici, Leuconostoc mesenteroides, $L$. lactis and $L$. salivarius. The latter represents $4 \%$ of the isolated strains and was found only in home-produced mawè. A wide range of species of lactic acid bacteria were present at the beginning of the fermentation period. Seven different species were detected in each of the mawè types, between 0 and $6 \mathrm{~h}$ of the fermentation period. But the number of isolated species was reduced towards the end of the fermentation period where L. fermentum (biotype cellobiosus) and L. fermentum or L. reuteri accounted for $90 \%$ of the species isolated, L. fermentum (biotype cellobiosus) being the most important.

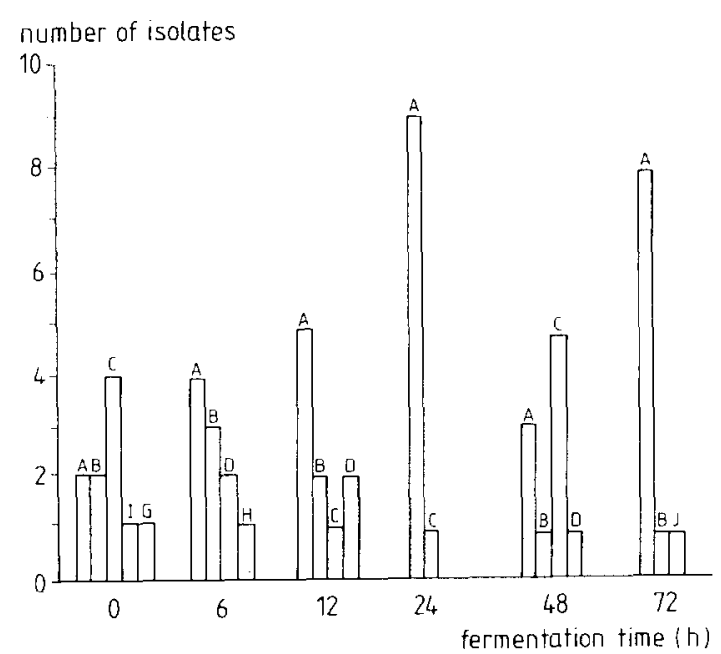

Fig. 1. Frequency distribution and succession of lactic acid bacteria isolated from home-produced mawè. A, L. fermentum (biotype cellobiosus); B, L. fermentum or L. reuteri; C, L. breits; D, $L$. salicarius; $\mathrm{G}$, Leuconostoc mesenteroides; $\mathrm{H}$, Lactococcus lactis; I, L. lactis; J, I. buchneri. 


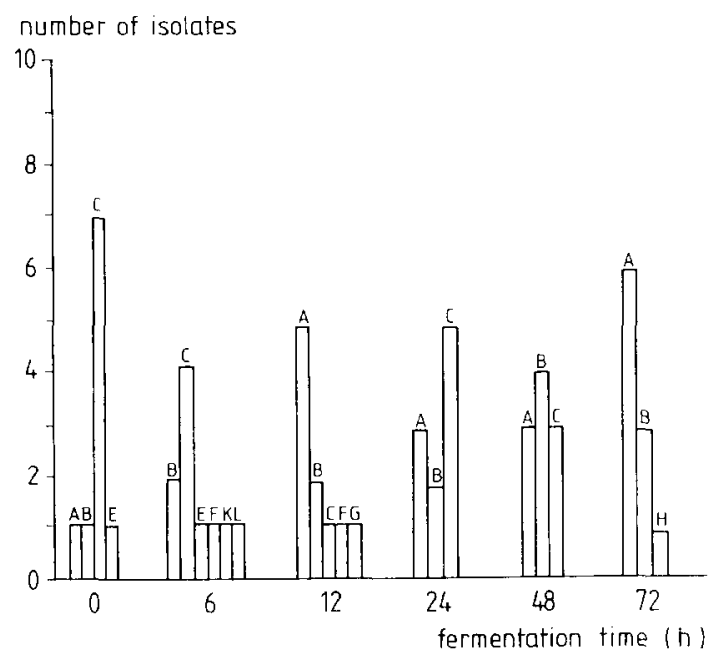

Fig. 2. Frequency distribution and succession of lactic acid bacteria isolated from commercial mawè. A, L. fermentum (biotype cellobiosus); B, L. fermentum or L. reuteri; C, L. breis; E, L. confusus; F, Pediococcus pentosaceus; G, Leuconostoc mesenteroides; H, Lactococcus lactis; K, L. curiatus; L, Pediococcus acidilactici.

Characteristics of the strains of lactic acid bacteria isolated are summarized in Table 1. Most of the L. fermentum (biotype cellobiosus) strains identified were unable to ferment esculin. All the isolated strains of $L$. fermentum or $L$. reuteri lacked the power to ferment cellobiose. Most of the L. brevis fermented amygdalin, cellobiose, mannose, salicin, trehalose and grew at $45^{\circ} \mathrm{C}$.

\section{Discussion}

Lactic acid bacteria have been associated with the spontaneous fermentation process of many plant foods. Fields et al. (1981) isolated $L$. fermentum, $L$. cellobiosus and Pediococcus acidilactici from naturally fermented corn meal. These species, as well as strains of $L$. buchneri and Pediococcus pentosaceus have also been isolated from traditional Kenyan uji (Mbugua, 1984), while L. brevis and $L$. salicarius have been isolated from busaa, a Kenyan sour maize beer (Nout, 1980). Adegoke and Babalola (1988) isolated L. fermentum and L. brevis from Nigerian fufu, while Oyewole and Odunfa (1990) found L. cellobiosus, L. brevis, L. confusus, $L$. lactis and Leuconostoc mesenteroides in this product. Leuconostoc mesenteroides, $L$. brevis and $L$. fermentum were isolated from fermenting tef dough (Gashe, 1985). Odunfa and Adeyele (1985) have isolated Lactococcus lactis from ogi baba. In many cases, $L$. plantarum was present in the fermenting product and dominated at the final stage of fermentation, due to its high acid tolerance (Akinrele, 1970; Nout, 1980; Mbugua, 1984; Kotzekidou and Roukas, 1986; Oyewole and Odunfa, 1990). No L. plantarum was isolated in the course of this 


\section{TABLE I}

Characteristics of lactic acid bacteria isolated during mawè fermentation

\begin{tabular}{|c|c|c|c|c|c|c|c|c|c|c|c|c|}
\hline \multirow{3}{*}{$\begin{array}{l}\text { Name of species ": } \\
\text { Number of strains: }\end{array}$} & \multicolumn{12}{|c|}{ Percentage of strains giving positive reactions } \\
\hline & A & B & $\mathrm{C}$ & D & $\mathrm{E}$ & $\mathrm{F}$ & G & $\mathrm{H}$ & I & $J$ & K & $\mathrm{L}$ \\
\hline & 49 & 23 & 31 & 5 & 2 & 2 & 2 & 2 & 1 & 1 & 1 & 1 \\
\hline \multicolumn{13}{|l|}{$\overline{\text { Fermentation of: }}$} \\
\hline Amygdalin & 10 & 0 & 81 & 0 & () & 100 & 0 & 100 & 0 & 0 & 0 & 100 \\
\hline 1-Arabinose & 82 & 48 & 68 & 60) & 0 & 100 & 100 & 50 & 0 & 0 & 0 & 100 \\
\hline Cellobios & 24 & 0 & 97 & 40) & 100 & 100 & 0 & 100 & 0 & 0 & 100 & 100 \\
\hline Esculin & 24 & 0 & 100 & 0 & 100 & 100 & 0 & 100 & 0 & 0 & 100 & 100 \\
\hline Fructose & 100 & 96 & 100 & 100 & 100 & 100 & 100 & 100 & 100 & 100 & 100 & 100 \\
\hline Galactose & 76 & 96 & 100 & 100 & 100 & 100 & 100 & 100 & 100 & 0 & 0 & 100 \\
\hline Glucose & 100 & 100 & 100 & 100 & 100 & 100 & 100 & 100 & 100 & 100 & 100 & 100 \\
\hline Gluconate & 90 & 96 & 100 & 60 & 100 & 0 & 50 & 50 & 100 & 100 & 100 & () \\
\hline Laclose & 61 & 65 & 71 & 100 & 0 & 0 & 0 & 100 & 100 & 0 & 0 & 0 \\
\hline Maltose & 100 & 96 & 100 & 80 & 100 & 100 & 100 & 100 & 100 & 100 & 100 & 0 \\
\hline Mannitol & 12 & 17 & 13 & 100 & 0 & 0 & 0 & 0 & 0 & 0 & 0 & () \\
\hline Mannose & 71 & 74 & 100 & 100 & 100 & 100 & 100 & 100 & 100 & 0 & 100 & 100 \\
\hline Melezitose & 0 & 4 & 3 & 0 & 0 & 0 & 0 & 0 & 0 & 0 & () & 0 \\
\hline Melibiose & 94 & 100 & 97 & 100 & 50 & 50 & 100 & 100 & 100 & 0 & () & (1) \\
\hline Ralfinose & 90 & 100 & 100 & 100 & 0 & 0 & 100 & 100 & 100 & 100 & 0 & 0 \\
\hline Rhamnose & 10 & 4 & 16 & 60 & 0) & 50 & 0 & () & 0 & 0 & 0 & 0 \\
\hline Ribose & 98 & 96 & 100 & 60 & 100 & 100 & 50 & 50 & 100 & 100 & 100 & 100 \\
\hline Salicin & 4 & () & 90 & 0 & 0 & 100 & 50 & 100 & 0 & 0 & 0 & 100 \\
\hline Sorbitol & 8 & 4 & 13 & 80 & 0 & 0 & 0 & 50 & 0 & 0 & () & 0 \\
\hline Trehalose & 80 & 78 & 97 & 100 & 50 & 100 & 100 & 100 & 100 & ) & 0 & 100 \\
\hline D-Xylose & 82 & 83 & 100 & 60 & 100 & 50 & 100 & 100 & 0 & () & 100 & 100 \\
\hline D-Arabinose & 2 & 0 & () & () & () & 0 & 0 & 0 & 0) & () & 0 & 0 \\
\hline 1.Xylose & 2 & () & () & () & () & 0) & 0 & 0 & 0 & 0 & 0 & () \\
\hline \multicolumn{13}{|l|}{$\beta$-Methyl-1)- } \\
\hline xyloside & 2 & 0 & 0 & () & () & () & 0 & 0 & () & 0 & 0 & 0 \\
\hline \multicolumn{13}{|l|}{$\alpha-$ Methyl-1)- } \\
\hline glucoside & 2 & 0 & 6 & 0) & 0 & 0 & 0 & 0 & 0 & 0 & 0 & 0 \\
\hline \multicolumn{13}{|l|}{$N$-Acetyl } \\
\hline glucosoamine & 31 & 26 & 100 & 100 & 100 & 100 & 100 & 100 & 0 & 0 & 100 & 100 \\
\hline Arbutin & 2 & 4 & 84 & 0 & 0 & 100 & 50 & 100 & 0 & () & () & 100 \\
\hline Saccharose & 100 & 100 & 97 & 100 & 100 & 0 & 100 & 100 & 100 & 100 & 0 & 0 \\
\hline Starch & 0 & 0 & 3 & 0 & 0 & 0 & 0 & 50 & 0 & 0 & 0 & 0 \\
\hline Xylitol & 0 & 0 & 0 & 40 & 0 & 0 & 0 & 0 & 0 & 0 & 0 & 0 \\
\hline Gentiobiose & 24 & 4 & 97 & 0 & 100 & 100 & 50 & 100 & 0 & 0 & 100 & 100 \\
\hline D-Turanose & 0 & 0 & 3 & 0 & 0 & () & 0 & 0 & 0 & 0 & () & 0 \\
\hline 1)-Tagatose & 6 & 9 & 74 & 0 & 0 & 100 & 50 & 100 & 0 & ) & 0 & 100 \\
\hline 1.-Fucose & 0 & () & 11 & 0 & 0 & 0 & 0 & 0 & 0 & 0 & 0 & 100 \\
\hline 1)-Arabitol & 2 & 9 & 0 & 80 & 0 & 0 & 0 & 0 & 0 & 0 & 0 & 0 \\
\hline 1.-Arabitol & 0 & 0 & 3 & 0 & 0 & 0 & 0 & 0 & 0 & 0 & 0 & 0 \\
\hline 5-Keto-gluconate & 90 & 70 & 68 & 40 & 0 & () & 0 & 50 & 100 & 0 & 0 & 0 \\
\hline Growth at $15^{\circ} \mathrm{C}$ & 39 & 26 & 100 & 0 & 100 & 100 & 100 & 100 & 0 & 100 & 100 & 100 \\
\hline Growth at $45^{\circ} \mathrm{C}$ & 96 & 91 & 77 & 100 & 0 & 50 & 0 & 100 & 100 & 0 & 0 & 100 \\
\hline $\mathrm{NH}_{3}$ from arginine & 100 & 100 & 100 & 0 & 100 & 100 & 50 & 100 & 0 & 100 & 100 & 100 \\
\hline
\end{tabular}


TABLE I (continued)

\begin{tabular}{|c|c|c|c|c|c|c|c|c|c|c|c|c|}
\hline \multirow{3}{*}{$\begin{array}{l}\text { Name of species }{ }^{a} \text { : } \\
\text { Number of strains: }\end{array}$} & \multicolumn{12}{|c|}{ Percentage of strains giving positive reactions } \\
\hline & $\overline{\mathrm{A}}$ & B & $\mathrm{C}$ & $\mathrm{D}$ & $\mathrm{E}$ & $\mathbf{F}$ & G & $\mathrm{H}$ & 1 & $\mathbf{J}$ & $\mathrm{K}$ & $\mathbf{L}$ \\
\hline & 49 & 23 & 31 & 5 & 2 & 2 & 2 & 2 & 1 & 1 & 1 & 1 \\
\hline \multicolumn{13}{|l|}{$\begin{array}{l}\text { Fermentation of: } \\
\text { Morphology }\end{array}$} \\
\hline $\begin{array}{l}\text { Morphology } \\
\text { bacilli } \\
\text { cocci }\end{array}$ & 100 & 100 & 100 & 100 & 100 & 100 & 100 & 100 & 100 & 100 & 100 & 100 \\
\hline $\begin{array}{l}\text { Homo- } \\
\text { fermentation }\end{array}$ & & & & 100 & & 100 & & 100 & 100 & & & 100 \\
\hline $\begin{array}{l}\text { Hetero- } \\
\text { fermentation }\end{array}$ & 100 & 100 & 100 & & 100 & & 100 & & & 100 & 100 & \\
\hline
\end{tabular}

investigation on mawè which nevertheless acidifies from $\mathrm{pH} 6.1$ (initial) to $\mathrm{pH} 3.5$ (final product). The predominant lactic acid bacteria isolated in both types of mawè in this investigation belonged to the Betabacterium group, L. fermentum (biotype cellobiosus) being the most important. Oyewole and Odunfa (1990) reported $L$. cellobiosus to be the predominant lactic species in the unfermented cassava tubers for fufu production, but this species was not isolated beyond $36 \mathrm{~h}$ of fermentation. Kotzekidou and Roukas (1986) emphasized the domination of $L$. cellobiosus after 24 and $36 \mathrm{~h}$ of fermentation of okra, while $L$. fermentum and $L$. cellobiosus represented more than $50 \%$ of strains isolated in sorghum uji enriched at $45^{\circ} \mathrm{C}$ (Mbugua, 1984). Among heterolactic bacteria, the ability of $L$. cellobiosus to remove all detectable fermentable sugars from green beans and green bean juice, and to lower the $\mathrm{pH}$ to 3.52 has been reported (Chen et al., 1983a, 1983b). The present investigation confirms the predominant role of L. fermentum (biotype cellobiosus) in natural lactic fermentations.

Leuconostoc mesenteroides was recognized as initiating flora for many fermentation processes (Pederson, 1971; Gashe, 1985). Although this species was present in mawè, its number was very low. L. brevis was not isolated after $72 \mathrm{~h}$ of fermentation. This could be due to its inability to survive the high acidity produced in mawè after this fermentation period.

Strains of subgenus Betabacterium are not easily distinguishable; particularly the distinction between L. brevis and L. buchneri and between L. fermentum and L. cellobiosus is not clearly established from the biochemical characteristics of the species. In the present investigation, the only organism identified as $L$. buchneri was not able to fermented melezitose. On the other hand, three strains were identified as $L$. brevis although they ferment melezitose. Strains of $L$. brevis fermenting melezitose and strains of $L$. buchneri failing to ferment melezitose were reported (Kandler and Weiss, 1986; Mbugua, 1984). Presently, L. cellobiosus is considered as a biotype of L. fermentum. Furthermore, strains previously 
classified as $L$. fermentum based on the sugar fermentation pattern have been found to be representative of two species, $L$. fermentum and $L$. reuteri, exhibiting a $\mathrm{G}+\mathrm{C}$ content in the DNA of 52-54 and 40-42 mol\%, respectively. However, $L$. fermentum seems to be more widespread in lactic acid fermented substrates (Kandler and Weiss, 1986).

The lactobacilli belonging to the obligately heterofermentative Betabacterium group form lactic acid, acetic acid, carbon dioxide and ethanol from hexoses via the hexose monophosphate shunt (Kandler, 1984); these components contribute to the taste and the flavour of the product.

These organisms are probably also responsible for the increase in volume and the porous structure in naturally fermented mawè, through gas $\left(\mathrm{CO}_{2}\right)$ production. This leavening action of heterofermentative bacteria was also reported by Christian (1970) in Ghanaian maize dough, and Gashe (1985) who considered the leavening action to be due to the activities of Enterobacteriaceae as well. The porous structure of the dough is desirable because it facilitates the disintegration of particles of mawè during the preparation of a granulated porridge (aklui).

\section{Acknowledgements}

Facilities and technical assistance provided by the Dutch-Beninese University Cooperation Programme, by the European Community (through the "Institut de Recherche Agronomique Tropicale"-Montpellier), and by the International Foundation for Science to one of us (D.J.H), are gratefully acknowledged. The authors thank Mr Boniface Ayenan for his assistance.

\section{References}

Adegoke. G.O. and Babalola, A.K. (1988) Characteristics of micro-organisms of importance in the fermentation of fufu and ogi, two Nigerian foods. J. Appl. Bacteriol. 65, 449-453.

Akinrele, I.A. (1970) Fermentation studies on maize during the preparation of a traditional african starch-cake food. J. Sci. Food Agric. 21, 619-625.

Chen, K.H., McFeeters, R.F. and Fleming, H.P. (1983a) Fermentation characteristics of heterolactic acid bacteria in green been juice. J. Food Sci. 48, 962-966.

Chen. K.H., McFeeters, R.F. and Fleming, H.P. (1983b) Complete heterolactic acid fermentation of green beans by Lactobacillus cellobiosts. J. Food Sci. 48, 967-971.

Christian, W.F.K. (1970) Lactic acid bacteria in fermenting maize dough. Ghana J. Sci. 10. 22-28.

Cox, R.P. and Thomsen, J.K. (1990) Computer-aided identification of lactic acid bacteria using the API 50 CHL system. Lett. Appl. Microbiol. 10, 257-259.

Fields. M.L., Hamad M. and Smith, D.K. (1981) Natural lactic acid fermentation of corn meal. J. Food Sci. 46, 900-902.

Gashe, B.A. (1985) Involvement of lactic acid bacteria in the fermentation of tef (Eragrostis tef), an ethiopian fermented food. J. Food Sci. 50, 800-801.

Harrigan, W.F. and McCance, M.E. (1976) Laboratory methods in food and dairy microbiology. London: Academic Press.

Hounhouigan, D.J., Nout, M.J.R., Nago, C.M., Houben, J.H. and Rombouts, F.M. (1992) Composition and microbiological and physical attributes of mawè, a fermented maize dough from Benin. Int. J. Food Sci. Technol. in press. 
Kandler, O. (1984) Current taxonomy of lactobacilli. Dev. Industr. Microbiol. 25, 109-123.

Kandler, O. and Weiss, N. (1986) Regular non-sporing Gram-positive rods. In: Sneath, P.H.A., Mair, N.S., Sharpe, M.E. and Holts, J.G. (Eds.) Bergey's Manual of Systematic Bacteriology Vol. 2. Baltimore: Williams and Wilkins, pp. 1208-1234.

Kotzekidou, P. and Roukas, T. (1986) Characterization and distribution of lactobacilli during lactic fermentation of okra (Hibiscus esculentus). J. Food Sci. 51, 623-625.

Mbugua, S.K. (1984) Isolation and characterisation of lactic acid bacteria during the traditional fermentation of uji. East African Agric. Forestry J. 50, 36-43.

Nout, M.J.R.(1980) Microbiological aspects of the traditional manufacture of busaa, a kenyan opaque maize beer. Chem. Mikrobiol. Technol. Lebensm. 6, 137-142.

Odunfa, S.A. and Adeyele, S. (1985) Microbiological changes during the traditional production of ogi-baba, a west african fermented sorghum gruel. J. Cereal Sci. 3, 173-180.

Oyewole, O.B. and Odunfa, S.A. (1990) Characterization and distribution of lactic acid bacteria in cassava fermentation during fufu production. J. Appl. Bacteriol. 68, 145-152.

Pederson, C.S. (1979) Microbiology of Food Fermentations, 2nd Edn. Westport CT: AVI Publishing Co. Inc. 